\title{
A construção do Espaço Europeu de Educação Superior
}

O Processo de Convergência Européia deu seu último passo para a unificação da Europa em relação à educação universitária. Isso ocorreu como conseqüência de iniciativas realizadas há mais de uma década, em programas desenvolvidos pela União Européia, que vêm_aumentando e incentivando a mobilidade e o intercâmbio do professorado e alunos entre as diversas universidades da Comunidade que participam desse processo.

Da mesma forma, esse processo implica a criação de um sistema de reconhecimento de créditos, entre todas as universidades e instituições de educação superior, os quais dão ao aluno a possibilidade de aceder, após contemplar seus estudos universitários, a um mercado de trabalho livre entre todos os países-membros, com a comprovação de um certificado denominado Suplemento Europeu ao Título.

A nova sociedade do conhecimento na Europa precisa dessa unificação de critérios para a elaboração dos conteúdos curriculares em todos os cursos. Uma formação universitária unificada, atualmente, permitirá melhorias na qualidade do ensino superior para atender às necessidades socioculturais da Comunidade. Uma sociedade européia que pretende eliminar fronteiras e barreiras não pode ignorar a importância dessa unificação na formação cultural de seus habitantes.

O Espaço Europeu de Educação Superior (EEES) consolida-se ante as declarações de La Sorbona (1998) e de Bolonia (1999), nas quais os ministros dos primeiros países europeus integrados no Projeto (Reino Unido, França, Alemanha e Itália) pedem aos membros que não desenvolvam somente atividades que constituam um mercado de passagem de produtos, mas que seja também um espaço comum para o conhecimento. Essas atividades estão centradas em uma série de atuações concretas, como:

- Adotar um sistema de títulos universitários compreensível, que permita a adoção de um Suplemento Europeu ao Título para promover a livre circulação profissional e laboral nos sistemas educativos superiores europeus.

- Estabelecer um sistema de elaboração de diplomas centrado em dois ciclos. Um primeiro ciclo ajustado à demanda do mercado de trabalho europeu com qualificação apropriada; um segundo ciclo dirigido a uma pósgraduação do tipo mestrado elou doutorado.

- Determinar um sistema de transferência de créditos europeus (ECTS - sigla do inglês European Credits Transfer System), que sejam revalidados entre as universidades para favorecer a circulação dos diplomas e alunos.

- Fomentar igualmente os programas de circulação para estudos em outras universidades européias.

- Desenvolver critérios e metodologias educativas que proporcionem a cooperação européia e, com isso, garantir mais qualidade nos processos educativos e em seus resultados.

- Impulsionar, como nova iniciativa, o aprendizado ao longo da vida como elemento fundamental para competir em nível europeu, adaptar-se continuamente à demanda social do formando e aumentar a qualidade e a competência profissional.

- Promover de forma mais ativa o papel da universidade e de seus alunos no processo de Convergência Européia, assim como nas iniciativas que estão em andamento, para incentivar e tornar atraente tudo que está relacionado a essa mudança educativa, mediante sistemas de garantia de qualidade e mecanismos de comprovação e certificação.

Para o ano de 2007, pretende-se alcançar os objetivos de colocar em prática os modelos de qualidade em todo território da Comunidade, expedir e reconhecer os diplomas em conjunto e de doutorados e proporcionar oportunidades aos estudantes para que possam realizar itinerários flexíveis no curso superior. $O$ ano de 2010 foi dado como data obrigatória para que todo o processo de inovação educativa nas universidades européias seja colocado em prática.

O sistema europeu de créditos considera crédito a quantidade total de trabalho do estudante, definido como a unidade de valorização da atividade acadêmica, além das horas dadas do corpo docente e o estágio que recebe do professor. Os créditos contemplariam, desse modo, o tempo de estudo, provas, pesquisas bibliográficas, trabalhos individuais ou em grupo, prática no magistério e dedicação ao estágio, entre outros. Cada crédito equivale a 25 até 30 horas, totalizando em 60 créditos o trabalho total de cada aluno durante o curso acadêmico. Um semestre equivale a 30 créditos, com uma média aproximada de 40 semanas de curso acadêmico e 40 horas de trabalho durante a semana, independente do curso.

Este novo sistema supõe uma mudança da mentalidade nos processos de ensino e aprendizagem, o que obriga a formar novos guias docentes e sistemas de avaliação. Tais inovações já estão sendo colocadas em prática, pelas universidades espanholas, por meio de projetos de inovação educativa que os docentes começaram com os alunos para introduzir pouco a pouco o novo modelo de sistema educativo. 
Talvez, o mais inovador de todo o projeto foi descobrir o que será avaliado agora no aluno. A nova normativa introduziu a avaliação das competências que o aluno deverá alcançar em cada curso, por meio das diferentes habilidades, destrezas e capacidades, de acordo com os conteúdos curriculares que está freqüentando. Essas competências classificam-se como genéricas ou transversais, iguais para todos os cursos; as específicas e próprias de cada curso; e as curriculares e concretas de cada matéria.

Os cursos superiores ficam estruturados em dois níveis. No Primeiro Nível ou Grau, o aluno deve alcançar as competências genéricas ou transversais, assim como as próprias de cada curso, para aceder a uma formação integral e profissional que lhe permita a integração no mercado de trabalho. O aluno deve "aprender a aprender" e se integrar aos processos educativos com uma participação mais ativa e colaboradora. Este primeiro ciclo é formado por 180 créditos e 60 adicionais europeus (ECTS) para que possa se integrar no mercado de trabalho.

Na Espanha, os estudos de Enfermagem ficam estruturados em quatro anos. Nos três primeiros deve-se cursar 180 créditos, no quarto ano há 60 restantes para a realização de um estágio e a apresentação de um projeto de conclusão de curso.

Mesmo que em 2007 não se façam públicas as definitivas Diretrizes Gerais dos Estudos de Educação Superior Europeus na Espanha, já se sabe que, no planejamento de estudo, as disciplinas desaparecem na forma em que hoje estão estruturadas, assim como os descritores e as áreas de conhecimento. Os conteúdos ficam integrados conforme as metas de ensino. Como exemplo, temos as disciplinas Materno-Infantil, Médico-Cirúrgico e Geriatria, que ficam englobadas no que se denomina "As diferentes etapas da vida".

A Pós-Graduação, ou Segundo Nível, de acordo com as declarações européias, dá lugar à aquisição do Mestrado elou Doutorado, cursando-se 60 créditos que, somados aos 240 do curso de graduação, possibilitam a realização da tese de Mestrado elou dissertação de Doutorado. Isso também ocorre no curso de Enfermagem. As universidades elaborarão os cursos de Pós-Graduação para a realização dos Mestrados, com objetivos formativos mais específicos e a finalidade de aprofundamento intelectual, potencializando a criatividade e o espírito crítico, possibilitando a realização de Mestrados em mais de uma universidade (Mestrado da União Européia) e a expedição de um diploma conjunto.

A nova estruturação na Espanha, referente ao ensino nas universidades de Pós-Graduação de caráter oficial, fica regulamentada pelo Artigo 88.2 da Lei Orgânica das Universidades, de 21 de dezembro de 2005. Encerra-se, assim, um longo processo de inovação educativa superior, na qual o país se integra, juntamente com outras nações européias, à construção de um Espaço Europeu de Educação Superior, dentro do Programa de Convergência Européia, para a estruturação do ensino universitário em cursos regulares de Pós-Graduação.

O estudante de Enfermagem, ao terminar seus ciclos, poderá aceder, de forma igual em todas as disciplinas, ao Suplemento Europeu ao Título ou à revalidação do diploma que lhe será conferido pela universidade, que informará os estudos realizados e as competências e capacidades adquiridas, que vão permitir ao formando a livre circulação pelo mercado europeu como diplomado em Enfermagem.

A comprovação acadêmica constitui a chave para alcançar a qualidade, sendo que cada país europeu criou, antes de iniciar o processo, um sistema de garantia de qualidade que avaliou os cursos universitários atuais em relação à demanda dos formandos. Na Espanha, criou-se, em 2003, a Agência Nacional para Avaliação da Qualidade e Comprovação (Agencia Nacional para la Evaluación de la Calidad y Acreditación-ANECA), dentro de um Plano Nacional de Avaliação dos cursos universitários.

A ANECA, após ter realizado diferentes avaliações nos cursos das universidades espanholas, tem como meta grandes desafios para alcançar seus objetivos e conseguir a comprovação e o certificado europeu, no processo já obrigatório de integração ao Espaço Europeu de Educação Superior no ano de 2010. 